\title{
POTENSI PANGAN FUNGSIONAL DAN PERANNYA DALAM MENINGKATKAN KESEHATAN MANUSIA YANG SEMAKIN RENTAN-MINI REVIEW
}

\author{
Abbas \\ Jurusan Ilmu Peternakan \\ Fakultas Sains dan Teknologi UIN Alauddin Makassar \\ J1. Sultan Alauddin No. 63, Kabupaten Gowa, Sulawesi Selatan. 92113 \\ E-mail: adolf_scfm@yahoo.co.uk
}

\begin{abstract}
This work was aimed to review not only variations and defenition of functional food as well as its positive impact on health but also diseases which correspond with poor diet and its correlation to certain health status, consumers' attitude and perception on functional food and potential of food from farm-based become functional food. There are 14 groups of bioactive as ingridient of food which have strong correlation toward status and sort of helath for instance, prebiotics and probiotics. As an effort to avoid the occurence of some diseases due to low nutrient diet, community development in terms of advocation and education play pivotal role on the impotance of functional food consumption. Yet, it is need support from local government as nearest authority to community and other stakeholders. Involving all stakelholders would be maximizing functional food production and it could be maintained its sustainability.
\end{abstract}

Keywords: bioactive, diet, functional food, prebiotics, probiotics

\section{PENDAHULUAN}

Derdapat beberapa faktor yang menjadi penggugah kesadaran dan pembangkit kebutuhan pangan fungsional (Suter, 2013) antara lain: tingginya keraguan konsumen terhadap jenis makanan dan minuman tertentu, prevalensi penyakit degeneratif yang terus tumbuh dan biaya pemeliharaan kesehatan yang besar. Dengan tingkat pendapatan perkapita yang masih rendah (3.927 USD atau Rp. 56 Juta), maka pangan fungsional menjadi komoditi yang permintaan pemenuhannya tak bisa dihindari dan terus meningkat.

Istilah pangan fungsional pertama kali diciptakan di Jepang pada tahun 1984, saat pemerintah Jepang menginvestasikan Yen dalam jumlah yang besar, untuk meneliti pangan fungsional atau pangan yang spesifik berperan positif terhadap kesehatan manusia. Pemerintah Jepang kemudian secara resmi mencatat dalam lembaran negara tentang pangan fungsional dan dikenal dengan FOSHU (Food for specified health used).

Saat istilah pangan fungsional bermigrasi ke Eropa, pangan fungsional didefenisikan sebagai produk makanan ataupun minuman yang kandungan nutrisinya memiliki manfaat lebih kepada manusia melampaui kandungan nutrisinya saja, baik untuk meningkatkan status kesehatan maupun untuk mencegah terjadinya berbagai kasus penyakit yang mungkin terjadi.

Belum ditemukan catatan resmi kapan istilah pangan fungsional mulai dikenal dan tersebar luas di Indonesia. Namun demikian, term ini telah menemukan momentumnya 
untuk mendapatkan perhatian dari akademisi dan masyarakat secara luas. Sehingga, perhatian dan kepedulian masyarakat untuk menghasilkan dan mengkonsumsi pangan fungsional juga mengalami peningkatan. Selain itu, kesadaran dan pengetahuan masyarakat akan beberapa penyakit kompleks seperti diabetes yang banyak terjadi tidak hanya di negara berkembang tetapi juga di negara maju ditengarai salah satu penyebabnya adalah diet dan gaya hidup yang tidak sehat.

Lebih jauh, pangan fungsional tidak hanya sekedar bahan makanan yang terdigesti dalam saluran pencernaan, tetapi sudah menjadi salah satu cara atau media untuk mencegah bahkan untuk mengobati beberapa penyakit tertentu, karena dengan beberapa kandungan esensialnya, pangan fungsional dapat memberikan dampak positif terhadap kesehatan manusia jika dikonsumsi secara teratur dan bervariasi dalam menu diet setiap hari.

Oleh karena itu, naskah ini mencoba mereview beberapa hasil riset terkait dengan pangan fungsional. naskah ini juga akan mengelaborasi lebih dalam tentang beberapa hal antara lain; jenis-jenis pangan fungsional, substansi penting dalam pangan fungsional, berbagai penyakit yang diasosiasikan dengan diet yang tidak sehat, bagaimana memahami persepsi serta perilaku atau kebiasaan masyarakat dalam pemenuhan pangan fungsional dan yang tak kalah penting adalah potensi pengembangan dan atau pengolahan produk pangan berbasis pertanian/peternakan menjadi pangan fungsional.

\section{METODE PENELITIAN}

\section{Review Jurnal}

Analisis terhadap beberapa artikel dilakukan dengan mereview lebih dari 50 (lima puluh) artikel ilmiah yang melaporkan isu-isu terkait pangan fungsional. Dengan menggunakan bantuan mesin pencari dan database bereputasi, yakni Science Direct, Pubmed, Scopus dan Google Scholar, scan pencarian artikel meliputi laporan hasil penelitian, artikel jurnal, buku teks, serta publikasi dari pemerintah maupun swasta yang diterbitkan antara tahun 2005 hingga 2020, dan untuk memudahkan dalam melakukan elaborasi isu-isu terkini soal pangan fungsional. Panjangnya rentang waktu publikasi yang dijadikan acuan tidak bisa dihindari karena beberapa hal, di antaranya karena publikasi tersebut diterbitkan oleh pemerintah.

\section{Koleksi dan Analisis Data}

Mengadopsi pendekatan analitik interpretatif yang digunakan oleh Bene (2018), analisis dititikberatkan pada isu-isu pangan fungsional yang hanya terbatas kepada beberapa faktor, seperti yang telah diuraikan pada bagian awal (pendahuluan) artikel ini.

Analisis yang digunakan terhadap beberapa data kuantitatif dan kualitatif yang sangat menarik perhatian adalah meta-analisis kemudian dielaborasi lebih dalam dengan metode deskriptif dari beberapa sudut pandang.

\section{HASIL DAN PEMBAHASAN}

\section{A. Defenisi dan Jenis Pangan Fungsional}

Dalam peraturan Badan POM No.HK.00.05.52.0685 tahun 2005 pasal 1 ayat 3 disebutkan bahwa pangan fungsional adalah pangan olahan yang mengandung satu atau 
lebih komponen fungsional yang berdasarkan kajian ilmiah mempunyai fungsi fisiologis tertentu, terbukti tidak membahayakan dan bermanfaat bagi kesehatan. Lebih jauh, pada pasal 5 dalam peraturan ini merinci terdapat 14 kelompok kandungan bioaktif dalam suatu bahan pangan sehingga dapat dikategorikan sebagai pangan fungsional, secara rinci dapat dilihat pada Tabel 1.

Tabel 1. Komponen-komponen bioaktif dalam pangan fungsional

\begin{tabular}{cll}
\hline No. & \multicolumn{1}{c}{ Komponen bioaktif } & \multicolumn{1}{c}{ Sumber utama } \\
\hline 1 & Vitamin & $\begin{array}{l}\text { Wortel, susu, jeruk sitrun, keju, telur, gandum, } \\
\text { daging, hati, kacang, ragi }\end{array}$ \\
\hline 2 & Mineral & Daging, kacang-kacangan, alga, sayur dan buah \\
\hline 3 & Gula alkohol & Jagung \\
\hline 4 & Asam lemak tak jenuh & Minyak ikan \\
\hline 5 & Peptida dan protein tertentu & Rumput laut, daging, susu, telur \\
\hline 6 & Asam amino & Daging, telur, susu, alga \\
\hline 7 & Serat pangan & Sayuran, buah kelapa \\
\hline 8 & Prebiotik & $\begin{array}{l}\text { Oats, pisang, buah berry, asparagus, bawang merah, } \\
\text { bawang putih }\end{array}$ \\
\hline 9 & Probiotik & Daging, susu, sayuran dan buah \\
\hline 10 & Kolin, Lesitin dan Inositol & Daging, sayuran \\
\hline 11 & Karnitin dan Skualen & Minyak ikan \\
\hline 12 & Isoflavon & Kacang kedelai, daun katuk \\
\hline 13 & Fitosterol dan Fitostanol & Kacang tanah, daun katuk, buah delima \\
\hline 14 & Polifenol & Alga, buah pisang, daun katuk, kulit buah manggis \\
\hline $\begin{array}{l}\text { Sumber: } \\
\text { et aleloye } \text { et al., 2020; } \text { Sudibya, 2008; } \text {;arditiani dan Susanti, 2013; } \text { Wahyuni, } \text { et al., 2013. }\end{array}$
\end{tabular}

Pada umumnya, secara alamiah hampir setiap bahan pangan memiliki komponen bioaktif dan relatif aman sebagai sumber nutrisi (Zhang et al., 2019). Namun ada beberapa atribut yang harus dimiliki oleh suatu bahan pangan hingga dapat dikategorikan sebagai pangan fungsional. Secara umum, setidaknya terdapat lima kelompok besar kategori pangan fungsional, antara lain; a) bahan pangan yang kandungan nutrisi dasarnya dikurangi atau ditingkatkan, misalnya sereal yang telah ditambahkan vitamin, minuman yang telah difortifikasi dengan vitamin antioksidan serta produk sapi perah yang telah dikurangi kadar lemaknya, b) produk yang secara alamiah tidak memiliki nutrisi tertentu lalu ditambahkan ke dalamnya, misalnya penambahan serat ke dalam jus buah, asam folat yang ditambahkan ke dalam margarin serta cemilan yang diperkaya stanol untuk menekan penyerapan kolesterol, c) produk berbahan dasar susu difermentasi dengan probiotik yang diseleksi berdasarkan kemampuan fungsionalnya untuk membantu proses pencernaan dan mencegah infeksi, beberapa produk telah ditambahkan oligosakarida untuk mendukung pertumbuhan bakteri tersebut, d) produk yang secara khusus diformulasikan untuk kebutuhan tertentu misalnya minuman untuk olahragawan ataupun sereal yang dibuat secara khusus untuk melepaskan karbohidrat dan menyuplai energi dalam jangka waktu yang cukup lama, dan e) bahan pangan yang mengandung bahan herbal untuk membantu mengatasi beragam masalah kesehatan (Taylor et al., 2005).

Komponen bioaktif yang dapat memberikan efek positif kepada kesehatan manusia (Ye et al., 2018), misalnya asam amino yang memiliki efek terapis seperti metabolisme metionin pada penyakit liver (Mato et al., 2008). Lantas bagaimana pangan fungsional memberikan pengaruh positif terhadap kesehatan manusia? Untuk 
menjawab pertanyaan ini, sangat penting untuk memahami apa yang terjadi pada proses pencernaan manusia saat memasukkan dan mencerna makanan dalam saluran gastrointestinal (GI) (Pang et al., 2012). Saluran pencernaan merupakan suatu sistem selektif yang berperan sebagai signal transducer, untuk bertukar informasi terkait nutrisi yang dibutuhkan oleh tubuh. Pangan fungsional memberikan manfaatnya melalui sel-sel yang perperan dalam pertukaran informasi tersebut. Kumar et al., (2015) melaporkan bahwa ketidakseimbangan jumlah koloni probiotik dalam saluran pencernaan manusia dapat mengakibatkan munculnya gangguan kesehatan dan efek negatif pada tubuh manusia, mengkonsumsi bahan makanan atau susu yang telah difermentasi dapat mencegah hal ini terjadi. Manfaat lain dari probiotik adalah bersifat anti karsinogenik, anti mutagenik, mencegah imflamasi saluran pencernaan dan meningkatkan metabolisme laktosa, serta dapat mengontrol alergi tertentu yang diakibatkan oleh diet yang tidak sesuai (Minervini et al., 2017).

\section{B. Substansi Penting Dalam Pangan Fungsional}

Protein dari bahan pangan sangat penting perannya dalam menjaga fungsi organ dan kesehatan manusia. Protein yang berasal dari tumbuhan dan hewan seperti: susu, telur, daging, kacang-kacangan, dan gandum merupakan substansi yang sangat esensial bagi manusia. Protein dari kacang kedelai (Chen et al., 2019), protein whey (Briviba et al., 2016), protein lentil (Avramenko et al., 2013), dan protein dari jamur (Jalali et al., 2015) dilaporkan memiliki beberapa efek positif dan peran fungsional fisiologis pada manusia.

Bioaktif peptida yang diperoleh dari beberapa derivat bahan pangan, dapat memberikan efek positif antara lain: menurunkan tekanan darah, anti inflamasi dan meningkatkan imunitas tubuh. Ada beberapa cara yang umum digunakan dalam memperoleh derivat peptida, yakni a) hidolisis dengan enzim menggunakan pepsin, tripsin, papain, dan beberapa protease lainnya, b) fermentasi dengan menggunakan mikroba, c) kombinasi enzim dan mikroba dan d) food processing dengan perlakuan panas dan tekanan (Tu et al., 2018). Amin et al., (2019) melaporkan bahwa salah satu sayuran yang termasuk dalam famili cucurbitaceae, labu, merupakan sumber utama komponen bioakif yang memiliki manfaat yang positif terhadap kesehatan.

Mineral sebagai bioaktif juga memiliki peran yang signifikan terhadap status kesehatan manusia, jika dikonsumsi dalam jumlah yang tepat. Umumnya berbentuk senyawa garam mineral yang dihasilkan dari proses inorganik. Mineral dengan kandungan potassium yang tinggi dan natrium yang rendah diklaim dapat memberikan efek positif terhadap sistem kardiovaskular dan membantu kinerja ginjal, beberapa mineral seperti $\mathrm{Mg}$ dan $\mathrm{Ca}$ juga penting peranannya dalam menyehatkan tulang (Ngoualem et al., 2020).

Aguiar et al., (2019) merinci beberapa jenis komponen bioaktif seperti mineral (selenium), flavanoid, polifenol, probiotik, prebiotik, sterol dan serat berasosiasi dengan sangat kuat terhadap status kesehatan tertentu, secara rinci dapat dilihat pada Gambar 1.

Hal yang sering diabaikan dalam mengkonsumsi bahan pangan adalah vitamin, anggapan bahwa vitamin merupakan kebutuhan tersier tubuh yang diperoleh dari bahan pangan seringkali menjadi pemicu kondisi ini. Namun, penting untuk dipahami bahwa vitamin merupakan kofaktor dalam proses metabolisme yang berlangsung secara enzimatis sehingga keberadaannya dalam menu diet menjadi sangat penting (Langer dan Lodge, 2014). Riboflavin misalnya, merupakan elemen yang esensial untuk fungsi biologis tubuh, sedangkan thiamin berperan dalam menjaga nafsu makan serta dapat 
mencegah penyakit beri-beri. Defisiensi thiamin juga dapat menyebabkan terjadinya proses retardasi dan kehilangan rambut (Asensi-Fabado and Munné-Bosch, 2010).

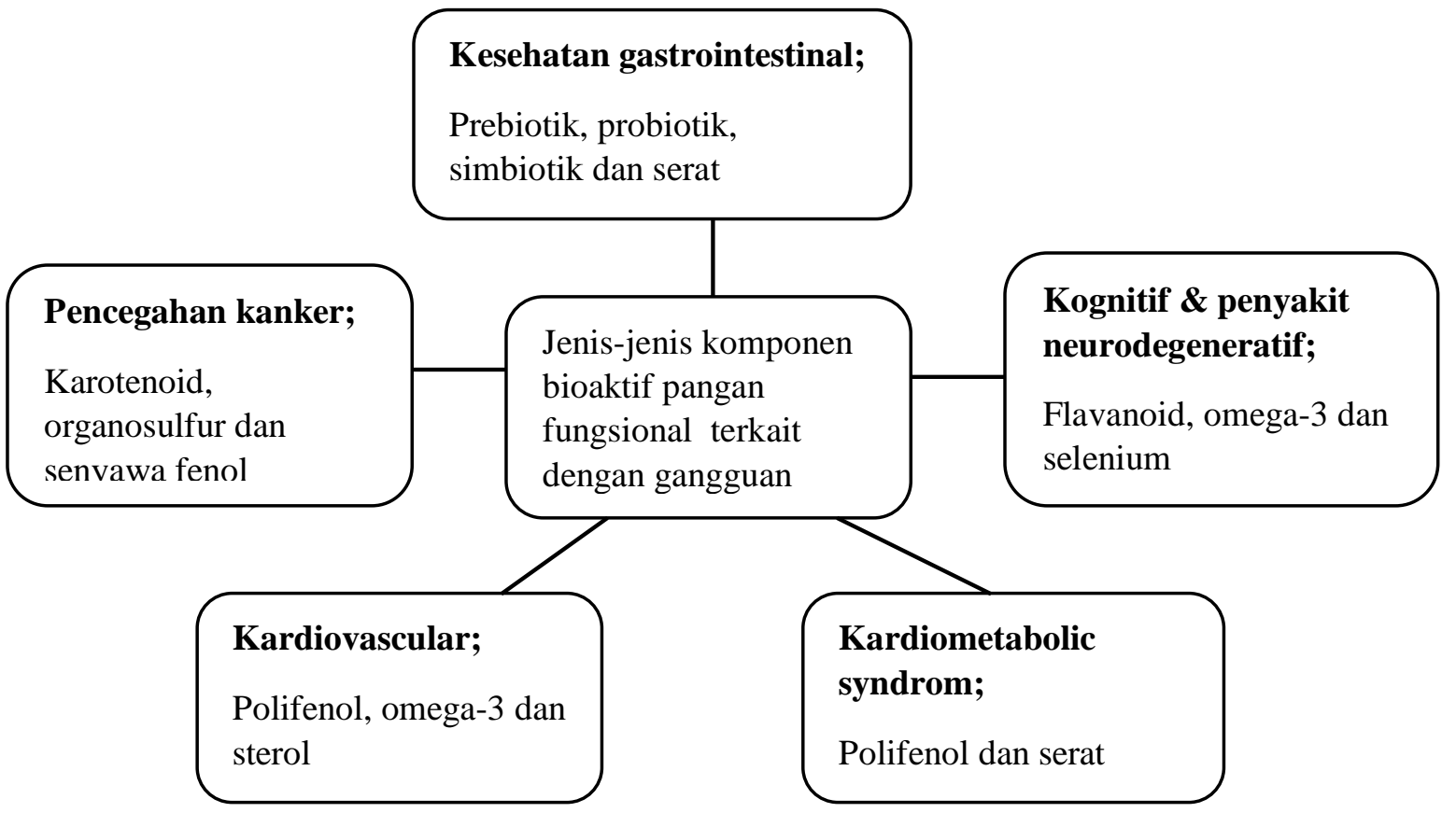

Gambar 1. Komponen bioaktif pangan fungsional dan kaitannya dengan aspek kesehatan tertentu (Aguiar et al., 2019)

\section{Beberapa Penyakit yang Diasosiasikan dengan Diet Tidak Sehat}

Berbagai penelitian telah mendokumentasikan dengan baik tentang hubungan yang sangat erat antara diet yang tidak sehat dengan berbagai penurunan fungsi sistem saraf (Solfrizzi et al., 2011; Luchsinger et al., 2017; Erro et al., 2018). Beberapa kasus yang sering terjadi dalam bahan makanan antara lain ditemukannya insektisida Fipronil di dalam telur, daur ulang terhadap gutter oil, beras yang terkontaminasi logam berat cadmium (Cd) dalam jumlah yang sangat banyak, makanan yang tercemar dengan salmonella dan kontaminasi melamin pada susu formula yang jika dikonsumsi oleh manusia akan memberikan dampak negatif terhadap status kesehatannya (Li et al., 2019).

Sudah umum dipahami bahwa mengkonsumsi bahan pangan dengan nutrisi yang tidak seimbang akan menghasilkan kondisi fisiologis yang tidak normal, dan bisa berujung pada beberapa penyakit kronis. Mengkonsumsi lemak secara berlebih dapat mengakibatkan kolesterol yang tinggi dalam darah, sementara mengkonsumsi garam terlalu banyak bisa berujung pada hipertensi. Sedangkan kekurangan kalsium dan zat besi bisa mengakibatkan osteoporosis dan anemia (Zawistowski, 2008).

Organisasi kesehatan PBB telah mempublikasikan prevalensi obesitas secara global sebesar $8,3 \%$ yang terdiri atas 382 juta orang, dan angka ini diperkirakan akan meningkat pada tahun 2035 menjadi 592 juta orang (WHO, 2017). Dan negara-negara di Asia menjadi epicenter dari meroketnya jumlah penderita diabetes dengan rasio jumlah penduduk yang rentan terhadap epidemi ini sekitar 60\% (Maheshwari et al., 2019).

Obesitas dapat meningkatkan resiko munculnya penyakit diabetes dan jantung koroner dan pengobatan terhadap penyakit tersebut relatif berbiaya tinggi bila 
dibandingkan dengan hanya merubah gaya hidup dan diet. Mencegah terjadinya obesitas selain menurunkan biaya pengobatannya, juga dapat meningkatkan harapan hidup atau life span manusia (van Baal, 2008).

Krebs et al., (2014), Semba et al., (2016) serta Watanabe dan Petri (2016) melaporkan bahwa diet atau menu makanan pada anak-anak yang rentan dengan gangguan disfungsi saluran pencernaan umumnya sangat rendah kualitasnya, kurang mengandung protein hewani, rendah kandungan kolin, asam lemak esensial dan beberapa mikro-nutrien lainnya.

Stres kronis sangat erat kaitannya dengan mood yang negatif seperti depresi ataupun cemas (Richter-Levin dan $\mathrm{Xu}, 2018$ ), kondisi ini mampu memicu beberapa perubahan dalam saluran gastrointestinal (GI) seperti perubahan komposisi mikrobiota dan penurunan fungsinya (Valles-Colomer et al., 2019).

Akrilamid dapat menyebabkan tumor pada beberapa organ seperti; paru-paru, uterus, mammalia gland dan pada otak (Kacar et al., 2018). Setelah dikonsumsi, akrilamid dengan mudah menyebar ke seluruh tubuh dan dengan mudah dijumpai pada berbagai organ misalnya: hati, jantung, otak bahkan bisa ditemukan pada plasenta manusia (Capuano dan Fogliano, 2011).

\section{Persepsi dan Kebiasaan Masyarakat dalam Pemenuhan Pangan Fungsional}

Permintaan konsumen terhadap bahan pangan yang beragam sepanjang tahun, prevalensi dan kenyamanan terhadap bahan pangan tertentu, mendorong pengembangan pengolahan produk pangan untuk memastikan ketersediaan bahan pangan yang aman dan sehat (Kumar et al., 2020).

Masih terdapat ambiguitas dalam memahami pangan fungisional oleh komsumen disebabkan oleh masih kurangnya informasi akurat yang terkait, meskipun menyadari dengan baik bahwa makanan yang dikonsumsi berkaitan erat dengan status kesehatan (Annunziata dan Vecchio, 2011).

Kebiasaan manusia dan mamalia pada umumnya dalam mengkonsumsi makanan dikontrol oleh signal sistem saraf yang kompleks (Atalayer et al., 2014). Namun, Purwasih dan Rahayu (2018) mendeskripsikan setidaknya tiga hal yang menjadi pemicu yang kuat terhadap keinginan konsumen dalam memenuhi kebutuhan pangan fungsional yakni berbagai riset terkini terkait dampak positif pangan fungsional, regulasi yang mendukung dan awareness masyarakat yang makin kuat terhadap pangan fungsional.

Keputusan konsumen dalam memilih produk pangan merupakan proses yang tidak sederhana dan melibatkan banyak faktor. Beberapa studi tentang pemilihan produk pangan menunjukkan bahwa beberapa faktor yang berperan dalam pemilihan produk pangan adalah awareness, attitude konsumen terhadap atribut produk (Syahlani, 2007).

Aspek lain yang tak kalah penting adalah pemerintah daerah yang berperan sangat penting dalam pemenuhan pangan sehat dan atau pangan fungsional, karena merupakan administratur yang paling dekat dengan komunitas masyarakat, lembaga pendidikan, rumah sakit, dan lembaga lainnya. Namun, tentu saja perlu dukungan dari banyak pihak untuk meningkatkan mutu dan standar layanan yang diberikan dalam upaya pemenuhan dan promosi pangan fungsional (Freudenberg, 2016). Leite et al., (2020) menggambarkan peran sentral dan hubungan erat antara pemerintah lokal dengan beberapa pemangku kepentingan dalam mempengaruhi pola konsumsi masyarakat seperti terlihat pada Gambar 2. 


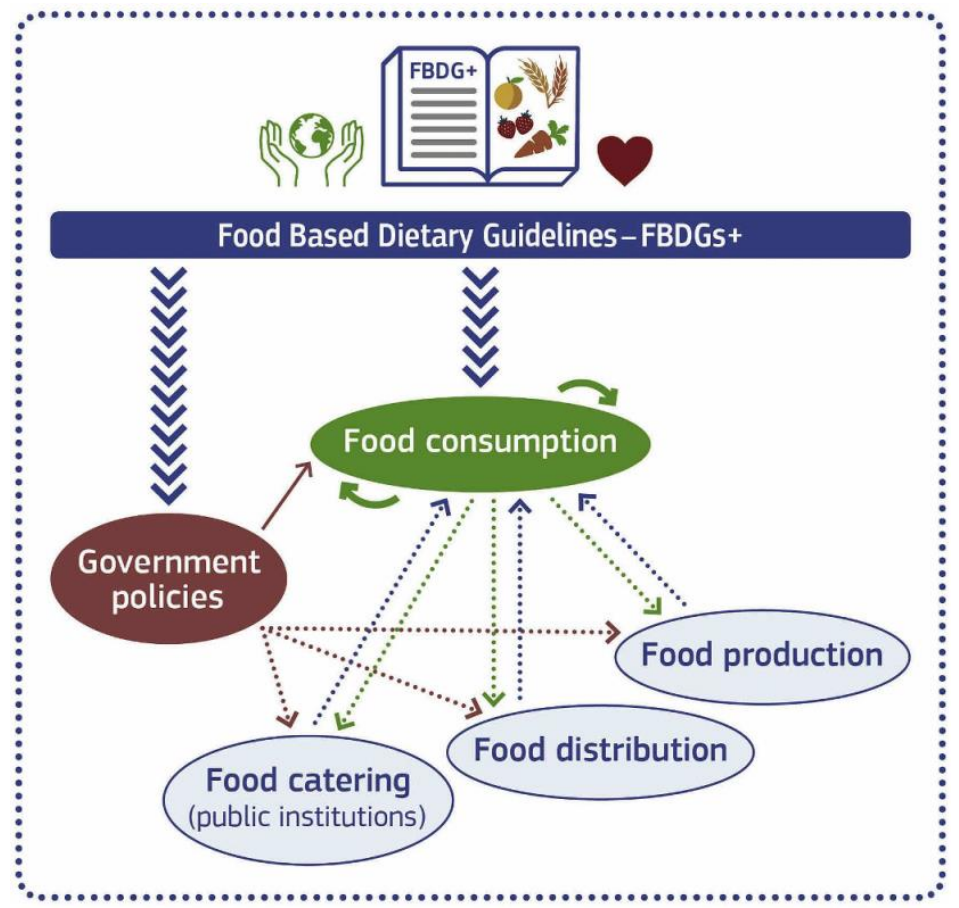

Gambar 2. Peran dan hubungan pemerintah dengan lembaga lain dalam mempengaruhi pola konsumsi (Leita et al., 2020)

\section{E. Potensi Pengembangan Produk Pangan Berbasis Pertanian/Peternakan sebagai Pangan Fungsional}

Produk pangan asal ternak telah berperan sangat penting dalam pemenuhan nutrisi manusia dengan konsumsi utama adalah daging, susu dan telur. Semua produk pangan yang berasal dari ternak berpotensi untuk diolah menjadi pangan fungsional karena beberapa kandungan atau atribut yang terdapat di dalamnya seperti bioaktif, peptida, asam lemak dan mineral. Namun tentu saja, semua produk pangan asal ternak tersebut tidak hanya mengandung substansi yang bersifat positif tetapi juga beberapa substansi yang berefek negatif, sehingga dalam pengolahannya perlu mendapatkan perhatian ekstra (Kralik et al., 2012).

Meskipun demikian, dengan perkembangan dan kemajuan teknologi telah memungkinkan untuk melakukan proses inovasi terhadap produk pangan yang menyesuaikan dengan kebutuhan spesifik setiap kelompok umur manusia. Kebutuhan nutrisi manusia berubah seiring dengan bertambahnya usia (Staveren and de Groot, 2011), misalnya pada manula kebutuhan akan nutrisi tertentu seperti kalsium, vitamin D dan protein mengalami peningkatan (Brownie, 2006).

Arihara (2014) mengusulkan beberapa strategi yang dapat dilakukan untuk mengembangkan bahan pangan fungsional atau produk pangan fungsional berbahan dasar daging, yang antara lain dapat dilakukan dengan memodifikasi komposisi karkas, memformulasikan kembali kandungan produk daging dengan menurunkan beberapa kandungannya seperti; reduksi kandungan lemak, kolesterol, kalori dan nitrat.

Samman et al., (2009) dan Horiuchi et al., (2019) menyimpulkan bahwa designer eggs yang diperkaya dengan omega-3 dan antioksidan merupakan salah satu alternatif pangan fungsional dan dapat meningkatkan status omega-3 dan antioksidan bagi yang mengkonsumsinya. 


\section{KESIMPULAN}

Pangan fungsional adalah pangan olahan yang tidak hanya mengandung satu atau lebih komponen fungsional yang berdasarkan kajian ilmiah mempunyai fungsi fisiologis tertentu tetapi juga memiliki beberapa atribut tertentu untuk dapat dikategorikan ke dalam kelompok spesifik ini.

Terdapat setidaknya empat belas jenis bioaktif yang memungkin suatu bahan pangan berfungsi sebagai pangan fungsional yang memiliki manfaat positif terhadap status kesehatan manusia yang mengkonsumsinya.

Jenis penyakit sangat variatif diasosiasikan dengan diet yang tidak sehat, peran sentral pemerintah daerah sangat penting dalam meningkatkan awareness masyarakat untuk memengaruhi gaya hidup pola konsumsi masyarakat.

Potensi pengembangan produk pangan fungsional berbasis produk pertanian/peternakan sangat memungkinkan untuk terus ditingkatkan, meskipun masih dibutuhkan inovasi dan riset yang beragam serta kompleks dalam memenuhi kebutuhan masyarakat yang terus menanjak seiring dengan pertambahan signifikan populasi manusia hampir di semua negara di dunia.

\section{DAFTAR PUSTAKA}

Adeloye, J.B., Osho, H. \& Idris, L.O. (2020). Defatted coconut flour improved the bioactive components, dietary fibre, antioxidant and sensory properties of nixtamalized maize flour. Journal of Agriculture and Food Research 2, 100042.

Aguiar, L.M., Geraldi, M.V., Cazarin, C.B.B. \& Junior, M.R.M. (2019). Functional food consumption and its physiological effects. Bioactive Compounds, 205-226. https://doi.org/10.1016/B978-0-12-814774-0.00011-6.

Amin, M.Z., Islam, T., Uddin, M.R., Uddin, M.J., Rahman, M.M. \& Satter, M.A. (2019). Comparative study on nutrient contents in the different parts of indigenous and hybrid varieties of pumpkin (Cucurbita maxima Linn). Heliyon 5, e02462. https://doi.org/10.1016/j.heliyon.2019.e02462.

Annunziata, A. \& Vecchio, R. (2011). Functional foods development in the European market: A consumer perspective. Journal of Functional Foods 3, 223- 228. doi:10.1016/j.jff.2011.03.011.

Arihara, K. (2014). Functional Foods. Encyclopedia of Meat Sciences, 2, 32-37. doi:10.1016/B978-0-12-384731-7.00172-0.

Asensi-Fabado, M. A. \& Munné-Bosch, S. (2010). Vitamins in plants: occurrence, biosynthesis and antioxidant function. Trends in plant science, 15(10), 582-592.

Atalayer, D., Astbury, N.M., Pantazatos, S.P., Geliebter, A., Gibson, C.D., McOuatt, H., and Puma, L. (2014). Sexually dimorphic functional connectivity in response to high vs. low energy-dense food cues in obese humans: An fMRI study. NeuroImage. http://dx.doi.org/10.1016/j.neuroimage.2014.05.054

Avramenko, N.A., Low, N.H. \& Nickerson, M.T. (2013). The effects of limited enzymatic hydrolysis on the physicochemical and emulsifying properties of a lentil protein isolate. Food Research International 51, 162-169.

Béné, C., Oosterveer, P., Lamotte, L., Brouwer, I.D., de Haan, S., Talsma, E.F., Khoury, C.K. \& Prager, S.D. (2019). When food systems meet sustainability - Current narratives and implications for actions. World Development, 113, 116-130. 
Briviba, K., Gräf, V., Walz, E., Guamis, B., \& Butz, P. (2016). Ultra high-pressure homogenization of almond milk: Physico-chemical and physiological effects. Food Chemistry 192, 82-89.

Brownie, A (2006). Why are elderly individuals at risk of nutritional deficiency? Int. J. Nurs. Pract, 12, 110-118.

Capuano, E. \& Fogliano, V. (2011). Acrylamide and 5-hydroxymethylfurfural (HMF): A review on metabolism, toxicity, occurrence in food and mitigation strategies. LWT-Food Sci Technol, 44(4), 793-810.

Chen, J., Mu, T., Goffin, D., Blecker, C., Richard, G., Richel, A. \& Haubruge, E. (2019). Application of soy protein isolate and hydrocolloids based mixtures as promising food material in 3D food printing. Journal of Food Engineering. doi: https://doi.org/10.1016/j.jfoodeng.2019.03.016.

Erro, R., Brigo, F., Tamburin, S., Zamboni, M., Antonini, A. and Tinazzi, M. (2018). Nutritional habits, risk, and progression of Parkinson disease. J. Neurol, 265, 12-23. https://doi.org/10.1007/s00415-017-8639-0.

Freudenberg, N. (2016). Healthy-food procurement: using the public plate to reduce food insecurity and diet-related diseases. www.thelancet.com/diabetes-endocrinology, 4. http://dx.doi.org/10.1016/ S2213-8587(16)00078-4.

Guntarti, A. (2016). Kadar polifenol total ekstrak etanol kulit buah manggis. Jurnal Farmasi dan Ilmu Kefarmasian Indonesia, 3(1).

Horiuchi, R., Singh, R.B., Takahashi, T., Basu, S.K., \& Tomar, R.S. (2019). Epigenetic modulation of nutritional factors in plants, animals, and humans: A new approach for developing functional foods. The Role of Functional Food Security In Global Health. Book chapter 39 (pp. 665-681). doi:https://doi.org/10.1016/B978-0-12-813148-0.000396.

Istiani, Y. (2010). Karakteristik senyawa bioaktif isoflavon dan uji aktifitas antioksidan dari ekstrak etanol tempe berbahan baku Koro pedang (Canavalia ensiformis). [Tesis]. Surakarta: Program Pascasarjana Universitas Sebelas Maret.

Jalali, B.M., Bogacki, M., Dietrich, M., Likszo, P. \& Wasielak, M. (2015). Proteomic analysis of porcine endometrial tissue during peri-implantation period reveals altered protein abundance. Journal of Proteomics, 125, 76-88.

Kacar S., Vejselova D., Kutlu H \& Sahinturk V. (2018). Acrylamide-derived cytotoxic, antiproliferative, and apoptotic effects on A549 cells. Hum Exp Toxicol, 37(5), 468-74.

Kralik, G., Grevic, M., \& Gajcevic-Kralik, Z. (2010). Animal products as functional foods. Feedstuffs, 52(1), 3-13.

Krebs, N.F., Miller, L.V., \& Hambidge, K.M. (2014). Zinc deficiency in infants and children: a review of its complex and synergistic interactions. Paediatr. Int. Child Health, 34, 279288.

Kumar, B.V., Vijayendra, S.V.N., \& Reddy, O.V.S. (2015). Trends in dairy and non-dairy probiotic products-a review. J. Food Sci. Technol, 52(10), 6112-6124.

Kumar, S., Mukherjee, A. \& Dutta, J. (2020). Chitosan based nanocomposite films and coatings: Emerging antimicrobial food packaging alternatives. Trends in Food Science \& Technology, 97, 196-209.

Lafarga, T., Acién-Fernández, F.G \& Garcia-Vaquero, M. (2020). Bioactive peptides and carbohydrates from seaweed for food applications: Natural occurrence, isolation, 
purification, and identification. Algal Research, 48, 101909. https://doi.org/10.1016/j.algal.2020.101909.

Langer, S. \& Lodge, J.K. (2014). Determination of selected water-soluble vitamins using hydrophilic chromatography: A comparison of photodiode array, fluorescence, and coulometric detection, and validation in a breakfast cereal matrix. Journal of Chromatography, 960, 73-81.

Leite, J.C., Caldeira, S., Watzl, B., \& Wollgast, J. (2020). Healthy low nitrogen footprint diets. Global Food Security, 24, 100342. https://doi.org/10.1016/j.gfs.2019.100342

Li, Y., Wang, Z., Sun, L., Liu, L., Xu, C. \& Kuang, H. (2019). Nanoparticle-based sensors for food contaminants. Trends in Analytical Chemistry. https://doi.org/10.1016/j.trac.2019.01.012.

Luchsinger, J.A., Noble, J.M., \& Scarmeas, N. (2007). Diet and Alzheimer's disease. Curr. Neurol. Neurosci. Rep, 7, 366-372.

Maheshwari, A., Saboo, B., Singh, R.B., Verma, N., Vargova, V., Pella, D., and Pella, D. (2019). Functional food security for prevention of diabetes melitus. Textbook: The Role of Functional Food Security In Global Health. Chapter 9. doi: https://doi.org/10.1016/B978-0-12-813148-0.00009-8.

Mato, J. M., Martínez-Chantar, M. L., \& Lu, S. C. (2008). Methionine metabolism and liver disease. 960 Annu. Rev. Nutr, 28, 273-293.

Minervini, F., DeAngelis, M., \& Gobbetti, M., (2017). Functional dairy products including pro/pre/symbiotics. Adv. Dairy Prod, 216.

Ngoualem, F.K., Nguimbou, R.M., Khan, A.M. \& Ndjouenkeu, R. (2020). Chemistry and functionalities of lake deposits and plant-based salts used in food preparations: A review. Food Chemistry, 321, 126674.

Pang, G., Xie, J., Chen, Q., and Hu, Z. (2012). How functional foods play critical roles in human health. Food Science and Human Wellness, 1, 26-60.

Purwasih, R., \& Rahayu, W.E. (2018). Potensi tepung ceker dan leher ayam sebagai food ingredient dan sumber pangan fungsional. Jurnal Ilmiah Ilmu dan Teknologi Rekayasa $1(2), 148-156$.

Richter-Levin, G., \& Xu, L. (2018). How could stress lead to major depressive disorder? IBRO Reports, 4, 38-43. https://doi.org/10.1016/j.ibror.2018.04.001.

Samman, S., Kung, P., Carter, L.M., Foster, J., Ahmad Z.I., \& Phuyal J.L. (2009). Fatty acid composition of certified organic, conventional and omega-3 eggs. Food Chem, 116, 91114.

Semba, R.D., Trehan, I., Li, X., Moaddel, R., Ordiz, M.I., Maleta, K.M., Kraemer, K., Shardell, M., Ferrucci, L. and Manary, M. (2017). Environmental enteric dysfunction is associated with carnitine deficiency and altered fatty acid oxidation. EBioMedicine, 17, 57-66.

Solfrizzi, V., Panza, F., Frisardi, V., Seripa, D., Logroscino, G., Imbimbo, B.P. \& Pilotto, A. (2011). Diet and Alzheimer's disease risk factors or prevention: the current evidence. Expert. Rev. Neurother, 11, 677-708.

Staveren, W.A., \& de Groot, L.P.G.M. (2011). Evidence-based dietary guidance and the role of dairy products for appropriate nutrition in the elderly. J. Am. Coll. Nutr, 30, 429-437.

Sudibya. (2008). Transfer omega-3 melalui kapsulisasi dan L-Karnitin pengaruhnya terhadap kandungan asam lemak daging dan sate kambing. Sains Peternakan, 6 (1), 18-25. ISSN 1693-8828. 
Suter, I.K. 2013. Pangan fungsional dan prospek pengembangannya. Makalah disajikan pada Seminar Sehari dengan tema "Pentingnya Makanan Alamiah (Natural Food) untuk Kesehatan Jangka Panjang" yang diselenggarakan oleh Ikatan Keluarga Mahasiswa (IKM) Jurusan Gizi Politeknik Kesehatan Denpasar, tgl. 18 Agustus 2013 di Denpasar.

Syahlani, S.P. (2007). Kajian efek iklan dan advetorial pada pengetahuan dan persuasi yang dirasakan: Studi proses adopsi pangan fungsional. Jurnal Ekonomi dan Bisnis Indonesia, 22(1), 92-109 .

Taylor, T.M., Davidson, P.M., Bruce, B.D. \& Weiss, J. (2005). Liposomal nanocapsules in food science and agriculture. Critical Reviews in Food Science and Nutrition, 45, 587605 .

Tu, M., Cheng, S., Lu,W. and Du, M. (2018). Advancement and prospects of bioinformatics analysis for studying bioactive peptides from food-derived protein: Sequence, structure, and functions. Trends in Analytical Chemistry, 105, 7-17.

Valles-Colomer, M., Falony, G., Darzi, Y., Tigchelaar, E. F., Wang, J., Tito, R. Y. and Raes, J. (2019). The neuroactive potential of the human gut microbiota in quality of life and depression. Nature Microbiology, 1. https://doi.org/10.1038/s41564-018-0337-x.

Van Baal, P.H. M., van den Berg, M., Hoogenveen, R.T., Vijgen, S.M.C. \& Engelfriet, P.M. (2008). Cost-effectiveness of a low-calorie diet and orlistat for obese persons: Modeling long-term health gains through prevention of obesity-related chronic diseases. Value in Health, 11(7).

Wahyuni, F.D., Asyiah, I.N. \& Hariyadi, S. (2013). Pengaruh ekstrak N-heksana daging buah delima putih (Punica granatum) terhadap penurunan kadar kolesterol darah pada tikus putih (Rattus norvegicus L.) dan pemanfaatannya sebagai buku suplemen. Pancaran, 2(4), 89-99.

Warditiani, N.K. \& Susanti, N.M. (2013). Uji aktivitas antihiperlipidemia ekstrak daun Katuk (Sauropus androgynus L.merr) pada tikus yang diinduksi hiperlipidemia. Laporan hasil akhir penelitian dosen muda. Jurusan Farmasi Fakultas Matematika dan IPA. Universitas Udayana.

Watanabe, K., Petri Jr., \& W.A., (2016). Environmental enteropathy: elusive but significant subclinical abnormalities in developing countries. EBioMedicine, 10, 25-32.

WHO. (2017). Diabetes fact sheet, updated July 2017. www.who.int/mediacentre/factsheets/fs312/en/ (Accessed: Oct 2019).

Ye, Q., Georges, N., \& Selomulya, C. (2018). Microencapsulation of active ingredients in functional foods: From research stage to commercial food products. Trends in Food Science \& Technology. Doi: 10.1016/j.tifs.2018.05.025.

Zawistowski, J. 2008. Regulation of functional foods in selected Asian countries in the Pacific Rim in Bagchi E. Nutraceutical and Functional Food Regulations in the United States and Around the World. Amsterdam: Academic Press.

Zhang, Z-M., Wu, X-1., Zhang, G-y., Ma, X., \& He, D-X. (2019). Functional food development: Insights from TRP channels. Journal of Functional Foods, 56, 384-394. 